\title{
Performance Evaluation of a Small Tractor with Biodiesel
}

\author{
Subrata Kr Mandal ${ }^{* 1}$, Ashok Kr. Prasad ${ }^{1}$, Atanu Maity ${ }^{1}$ and Krishnendu Kundu ${ }^{2}$ \\ ${ }^{I}$ CSIR-Central Mechanical Engineering Research Institute, M.G. Avenue, Durgapur, India \\ ${ }^{2}$ CSIR-CMERI-Centre of Excellence in Farm Machinery, Gill Road,Ludhiana, Punjab, India
}

*Corresponding author: subrata.mandal72@gmail.com

\begin{abstract}
Biodiesel, which is an alternative for diesel fuel, has gained considerable attention in the recent past and now gaining recognition among other available renewable fuels. In practice, biodiesel is produced through a process called transesterification in which organically derived oils are combined with alcohol (ethanol or methanol) in the presence of a catalyst to form ethyl or methyl ester. The produced biodiesel should meet the exiting standards for better performance in unmodified diesel engine. Use of biodiesel in a compression ignition engine was found to develop a highly compatible engine-fuel system with low emission characteristics. Two similar engines were operated using optimum biodiesel blend and mineral diesel oil, respectively. The additional lubricating property present in the fuel resulted in lower wear and improved life of moving components in a biodiesel-fuelled engine. However, this needed experimental verification and quantification. A series of experiments were thus conducted to see the fuel consumption of the various concentrations of biodiesel blends. $100 \%$ biodiesel showed lesser consumption rate compared to diesel oil.
\end{abstract}

Keywords: Biodiesel, esterification, Jatropha, transesterification, Vegetable oil

The world's economy depends upon the burning of fossil fuel equivalent of some 180 million barrels of oil each day. The consumption rate is equivalent to an annual burning of what nature took about one million years to accumulate as fossil deposits. The world at present is confronted with the twin crises of fossil fuel depletion and environmental degradation. Indiscriminate extraction and lavish consumption of fossil fuels have lead to reduction in underground-based carbon resources. The search for an alternative fuel, which promises a harmonious correlation with sustainable development, energy conservation, management, efficiency, and environmental preservation, has become highly pronounced in the present context (Agarwal et al. 2003).

More than 7 million diesel engines are being used in the Indian agricultural sector for various activities. It is impossible to do away with these existing systems and hence alternative fuels are being expeditiously 
sought. As far as the application in rural agricultural sectors of a developing country like India is concerned, such internal combustion engines should preferably utilize alternative fuels of bio-origin, which are locally available. With agricultural conditions prevailing in India, the adaptation of the fuel to the existing engines has been more pronounced compared to developing a new engine for available alternative fuel. This allows the replacement of diesel fuel by vegetable oils, and for a short-term fuel as a blend (Agarwal et al. 2003).

Alternative fuels are generally referred as cleaner fuels in comparison with gasoline or diesel fuels. While using a new fuel, it is extremely important to strike a balance among many conflicting parameters involving not only the performance and emission characteristics of the engine, but also the overall life of the system. The combustion-related properties of vegetable oils are somewhat similar to diesel oil (Agarwal, 1999). Neat vegetable oils or their blends with diesel pose various long-term problems in compression ignition engines, e.g., poor atomization characteristics, ring-sticking, injector-choking, injector deposits, injector pump failure, and lube oil dilution by crank-case polymerization. Such problems do not arise with shortterm engine operations. Sometimes, the engine fails catastrophically, when operated on neat vegetable oils continuously for a longer period. The properties of vegetable oils such as high viscosity, low volatility, and polyunsaturated character are responsible for these problems (Krawczyk, 1996; Teri, 1998).

\section{Indian scenario}

In India, the research and development of bio-diesel started from the mid 1980s. From 2003 on, Jatropha curcas developed fairly fast since many research institutes, universities, banks, farms, enterprises and NGOs began to engage in its breeding, propagation, plantation, cultivation and processing, etc. The Indian Government has attached much importance to bio-diesel. The Indian National Planning Commission has made clear development plan on bio-diesel. India will plant Jatropha curcas on a large scale, and bio-diesel derived from Jatropha curcas seeds will account for 20 percent of all diesel consumption in the country by 2020 .

In this paper performance of a small tractor namely Krishi Shakti was evaluated with different ratio of biodiesel and diesel blend in different field condition to observe various parameters. The results found very much satisfactory.

\section{Definition and Standard}

Biodiesel's definition has been a work in progress. Since the early 1900s, biodiesel has been defined as an alternative form of diesel fuel derived from vegetable oils or animal fats and alcohol. The definition of biodiesel was neither legally definable nor defensible in the World for about a century. This changed when biodiesel was registered with the U S Environmental Protection Agency (EPA) as a fuel and a fuel additive under section 211(b) of the Clean Air Act (Strong et al. 2004). With help from the American Society of Testing \& Materials (ASTM), subsequent legislation such as the Energy Policy Act (EPAct) helped further define biodiesel. In December 2001, the ASTM issued defined physical/chemical constraints for biodiesel and subsequently for mixtures of biodiesel with diesel fuel (Standards and Warranties 2006). An important distinction needs to be made between biodiesel and biodiesel blends. Biodiesel is commonly mixed with diesel No. 2 to form a biodiesel blend. A mixture of biodiesel and diesel is not biodiesel, but is referred to as a biodiesel blend. Pure biodiesel, also known as neat biodiesel, is commonly noted as 
B100, indicating that the fuel has 100 percent biodiesel (noted by the B100) and 0 percent diesel. The most common biodiesel blend is B20, which contains 20 percent biodiesel and 80 percent diesel.

Austrian Standardization Institute issued the first biodiesel fuel standard in 1991 as ON C 119063 for RME (Rapeseed Methyl Ester). This was as a successful attempt to define the quality of a fuel not by its feedstock source but by what was filled into the tank. Later in 1997, the DIN E 5160666 was published in Germany for FAME (Fatty Acid Methyl Ester), while other national standards were established in the CSSR, France, Italy, Sweden and USA. The most recent development is the completion of a CEN - European Committee for Standardization - draft standard for biodiesel with validity all over Europe. This work is still in progress and a final CEN-standard was published by mid 2003 under the new code of EN 14214 (Strong et al. 2004). Bureau of Indian Standards announced first specification for B 100 biodiesel (IS 15607 : 2005). Considerable assistance has been drawn from ASTM D 675102 and EN 14214 while preparing this standard. Table 1 lists the specification in the Indian standards. The maximum test methods for biodiesel fuel are just as it is for petrodiesel fuel like density, kinematic viscosity, flash point, sulfur content, carbon residue content, water content, copper corrosion, cetane number and acid value. And other remaining and most important methods are assisting towards the ASTM and EN standards.

Table 1: Indian Biodiesel standards (IS: 15607)

\begin{tabular}{|c|c|c|c|c|}
\hline \multirow{2}{*}{$\begin{array}{l}\text { Sl. } \\
\text { No. }\end{array}$} & \multirow[t]{2}{*}{ Characteristic } & \multirow[t]{2}{*}{ Requirement } & \multicolumn{2}{|c|}{ Method of Test, Ref to } \\
\hline & & & ISO/ASTM/EN & [P : ] of IS 1448 \\
\hline 1 & Density at $15^{\circ} \mathrm{C}, \mathrm{kg} / \mathrm{m}^{3}$ & $860-900$ & ISO 3675, 1S0 12185, D 4052 & [P:16/P: 32] \\
\hline 2 & Kinematic viscosity at $40^{\circ} \mathrm{C}, \mathrm{cSt}$ & $2.5-6.0$ & ISO 3104 & {$[\mathrm{P}: 25]$} \\
\hline 3 & Flash point $(\mathrm{PMCC}){ }^{\circ} \mathrm{C}$, Min & 120 & - & {$[\mathrm{P}: 21]$} \\
\hline 4 & Sulphur, mg/kg, Max & 50.0 & D 5453 & [P: 83] \\
\hline 5 & $\begin{array}{c}\text { Carbon residue (Ramsbottom) }{ }^{1} \text {, percent by } \\
\text { mass, Max }\end{array}$ & 0.05 & D 4530, ISO 10370 & - \\
\hline 6 & Sulfated ash, percent by mass, Max & 0.02 & ISO 6245 & {$[\mathrm{P}: 4]$} \\
\hline 7 & Water content, $\mathrm{mg} / \mathrm{kg}, \mathrm{Max}$ & 500 & D 2709, ISO 3733, IS0 6296 & [P: 40] \\
\hline 8 & Total contamination, $\mathrm{mg} / \mathrm{kg}$, Max & 24 & EN 12662 & - \\
\hline 9 & Copper corrosion. $3 \mathrm{~h}$ at $50^{\circ} \mathrm{C}$, Max & 1 & 1S0 2160 & [P: 15] \\
\hline 10 & Cetane No., Min & 51 & $1 \mathrm{~S} 05156$ & {$[\mathrm{P}: 9]$} \\
\hline 11 & Acid value, mg KOH/g, Max & 0.50 & - & {$[\mathrm{P}: 1 / \mathrm{Sec} \mathrm{I}]$} \\
\hline 12 & Methanol $^{2}$, percent by mass, Max & 0.20 & EN 14110 & - \\
\hline 13 & Ethanol $^{3}$, percent by mass, Max & 0.20 & - & - \\
\hline 14 & Ester content, percent by mass, Min & 96.5 & EN 14103 & - \\
\hline 15 & Free Glycerol, percent by mass, Max & 0.02 & D 6584 & - \\
\hline 16 & Total Glycerol, percent by mass, Max & 0.25 & D 6584 & - \\
\hline 17 & Phosphorous, mg/kg, Max & 10.0 & D 4951 & - \\
\hline 18 & Oxidation stability at $110^{\circ} \mathrm{C}, \mathrm{h}, \mathrm{Min}$ & 6 & EN 14112 & \\
\hline
\end{tabular}

${ }^{1}$ Carbon residue shall be run on 100 percent sample; ${ }^{2}$ Applicable for fatty acid methyl ester; ${ }^{3}$ Applicable for fatty acid ethyl ester; ${ }^{4}$ European method is under development. 
Biodiesel produced by a process called transesterification, where the vegetable oil or animal fat is first filtered, then processed with alkali to remove free fatty acids. It is then mixed with alcohol (usually methanol) and a catalyst (usually sodium or potassium hydroxide). The vegetable oil's triglycerides react to form esters and glycerol, which are then separated from each other and purified. The reaction mechanism for alkali-catalyzed transesterification required three steps. The first step is an attack on the carbonyl carbon atom of the triglyceride molecule by the anion of the alcohol (methoxide ion) to form a tetrahedral intermediate. In the second step, the tetrahedral intermediate reacts with an alcohol (methanol) to regenerate the anion of the alcohol (methoxide ion). In the last step, rearrangement of the tetrahedral intermediate results in the formation of a fatty acid ester and a diglyceride (Fig. 1). The same mechanism is for diglyceride to monoglyceride and monoglyceride to glycerol. In each step, one molecule of ester is formed (Ma et al. 1999).

$\begin{array}{|lll|}\text { 1. Triglyceride ( } \mathrm{TG})+\mathrm{R}^{\prime} \mathrm{OH} & \rightleftharpoons & \text { Diglyceride ( } \mathrm{DG})+\mathrm{R}^{\prime} \mathrm{COOR}_{1} \\ \text { 2. Diglyceride }(\mathrm{DG})+\mathrm{R}^{\prime} \mathrm{OH} & \rightleftharpoons & \text { Monoglyce ride }(\mathrm{MG})+\mathrm{R}^{\prime} \mathrm{COOR}_{2} \\ \text { 3. Monoglyce ride }(\mathrm{MG})+\mathrm{R}^{\prime} \mathrm{OH} & \rightleftharpoons & \text { Glycerol }(\mathrm{GL})+\mathrm{R}^{\prime} \mathrm{COOR}_{3}\end{array}$

Fig. 1: Mechanism of transesterification reaction

Biodiesel is a renewable fuel that can be manufactured from algae, vegetable oils, animal fats or recycled restaurant greases; it can be produced locally in most countries. It is safe, biodegradable and reduces air pollutants, such as particulates, carbon monoxide and hydrocarbons. Blends of 20 percent biodiesel with 80 percent petroleum diesel (B20) can generally be used in unmodified diesel engines. Biodiesel can also be used in its pure form (B100), but may require certain engine modifications to avoid maintenance and performance problems. Biodiesel has about 5-8\% less energy density, but better lubricity and more complete combustion can make the energy output of a diesel engine only $2 \%$ less per volume when compared to petro-diesel. The fuel blend ratio of 25:75 (treated jatropha oil: diesel) was found optimum based on the engine performance characteristics such as power, torque, smoke density and exhaust emission.

Bio-diesels play an important role in the ongoing balance between two major societal needs, viz., fuel economy and environment friendly Emissions. Bio-diesels can be produced in a way that does not cut into food supplies as Jatropha is non edible oil. Bio-diesel production reduces the dependency on imported oil and supports the agricultural sector (Huang et al. 2012). The properties of biodiesel are not the same as diesel fuels especially their high viscosity and low volatility. These properties strongly affect injection pressure injection timing and spray characteristics (Yamanae et al. 2001).

An increase in viscosity of biodiesel will result in poor atomization characteristics due to decreased cone angle during fuel injection (Ryan et al. 1984). The pre-heating of vegetable oil gives better performance than raw vegetable oil. It has been observed that viscosity reduces exponentially with temperature. It has also been observed that when pre-heated vegetable oil is injected into the cylinder, spray pattern and atomization character has improved. The injection pressure has an effect on the spray formation of biodiesel blends in CI engines (Nagaraj et al. 2003). 


\section{QUALITY OF BIODIESEL: EXPLANATION AND THEIR CONSEQUENCE}

The quality of biodiesel can be divided into two groups (Martin, 1996). The first group includes parameters, which are directly correlated with the petro diesel fuel specifications, while the second group describes the chemical composition and purity of fatty acids methyl ester (Table 2). With the view of storage and stability of biodiesel over a longer time span, some modifications have been done by including some important specification required like water content, iodine value and oxidative stability of biodiesel under defined conditions.

Table 2: Parameters for defining the quality of biodiesel

\begin{tabular}{|c|c|c|}
\hline Parameters & Units & Available standards \\
\hline \multicolumn{3}{|c|}{ General parameter for the quality of biodiesel } \\
\hline $\begin{array}{l}\text { Density and specific } \\
\text { gravity }\end{array}$ & at $15^{\circ} \mathrm{C}, \mathrm{kg} / \mathrm{m}^{3}$ & $\begin{array}{l}\text { IS : } 15607 \text {, ON C1191, Journal Official, DIN E 51606, UNI 10635, } \\
\text { SS } 1554 \text { 36, EN } 14214\end{array}$ \\
\hline Kinematic viscosity & $\begin{array}{l}\text { at } 40^{\circ} \mathrm{C} \text {, cSt or } \\
\mathrm{mm}^{2} / \mathrm{s}\end{array}$ & $\begin{array}{l}\text { IS : 15607, ON C1191, Journal Official, DIN E 51606, UNI 10635, } \\
\text { SS } 1554 \text { 36, ASTM D 6751, MBTI, EN } 14214\end{array}$ \\
\hline A. Flash point & ${ }^{\circ} \mathrm{C}$ & $\begin{array}{l}\text { IS : } 15607 \text {, ON C1191, Journal Official, DIN E 51606, UNI 10635, } \\
\text { SS } 1554 \text { 36, ASTM D 6751, MBTI, EN } 14214\end{array}$ \\
\hline Cetane number & - & $\begin{array}{l}\text { IS : 15607, ON C1191, Journal Official, DIN E 51606, SS } 1554 \text { 36, } \\
\text { ASTM D 6751, MBTI, EN } 14214\end{array}$ \\
\hline Carbon Residue, $10 \%$ & percent by mass & $\begin{array}{l}\text { IS : 15607, Journal Official, UNI 10635, ASTM D 6751, MBTI, } \\
\text { EN } 14214\end{array}$ \\
\hline Total acidity & $\mathrm{mg} \mathrm{KOH} / \mathrm{kg}$ & $\begin{array}{l}\text { IS : } 15607 \text {, ON C1191, Journal Official, DIN E 51606, UNI 10635, } \\
\text { SS } 1554 \text { 36, ASTM D 6751, MBTI, EN } 14214\end{array}$ \\
\hline Sulphur content & $\mathrm{mg} / \mathrm{kg}$ & IS : 15607, ASTM D 6751, EN 14214 \\
\hline $\begin{array}{l}\text { Ash content } \\
\text { (Sulphated) }\end{array}$ & percent by mass & IS : 15607, ON C1191, DIN E 51606, ASTM D 6751, EN 14214 \\
\hline Water content & $\mathrm{mg} / \mathrm{kg}$ & $\begin{array}{l}\text { IS : 15607, Journal Official, DIN E 51606, UNI 10635, SS } 1554 \text { 36, } \\
\text { ASTM D 6751, MBTI, EN } 14214\end{array}$ \\
\hline Iodine number & - & $\begin{array}{l}\text { IS : } 15607, \text { ON C1191, Journal Official, DIN E } 51606 \text {, SS } 1554 \text { 36, } \\
\text { MBTI, EN } 14214\end{array}$ \\
\hline
\end{tabular}

\section{Vegetable oil specific parameter for the quality of biodiesel}

\begin{tabular}{|c|c|c|}
\hline Methanol & percent by mass & $\begin{array}{l}\text { IS : } 15607, \text { ON C1191, Journal Official, DIN E 51606, UNI 10635, SS } \\
1554 \text { 36, EN } 14214\end{array}$ \\
\hline Ethanol & percent by mass & $\begin{array}{l}\text { IS : } 15607, \text { ON C1191, Journal Official, DIN E 51606, UNI 10635, SS } \\
155436, \text { EN } 14214\end{array}$ \\
\hline Mono-glycerids & percent by mass & IS : 15607, Official, DIN E 51606, UNI 10635, SS 1554 36, EN 14214 \\
\hline Di-glycerids & percent by mass & IS : 15607, Official, DIN E 51606, UNI 10635, SS 1554 36, EN 14214 \\
\hline Tri-glycerids & percent by mass & IS : 15607, Official, DIN E 51606, UNI 10635, SS 1554 36, EN 14214 \\
\hline Free glycerol & percent by mass & $\begin{array}{l}\text { IS : 15607, ON C1191, Journal Official, DIN E 51606, UNI 10635, SS } \\
15 \text { 54 36, ASTM D 6751, MBTI, EN } 14214\end{array}$ \\
\hline Total glycerol & percent by mass & $\begin{array}{l}\text { IS : } 15607, \text { ON C1191, Journal Official, DIN E 51606, ASTM D 6751, } \\
\text { MBTI, EN } 14214\end{array}$ \\
\hline Total contamination & $\mathrm{mg} / \mathrm{kg}$ & \\
\hline Phosphorous & $\mathrm{mg} / \mathrm{kg}$ & $\begin{array}{l}\text { IS : } 15607 \text {, ON C1191, Journal Official, DIN E 51606, UNI 10635, SS } \\
1554 \text { 36, ASTM D 6751, MBTI, EN } 14214\end{array}$ \\
\hline Sodium and Potassium & $\mathrm{mg} / \mathrm{kg}$ & IS : 15607, Journal Official, DIN E 51606, SS 1554 36, EN 14214 \\
\hline
\end{tabular}


Calcium and

$\mathrm{mg} / \mathrm{kg}$

IS : 15607

Magnesium

Oxidative stability

at $110^{\circ} \mathrm{C}, \mathrm{h}$

IS : 15607, EN 14214

IS : 15607: Indian standard; ON C1191: Austria; Journal Official: France; DIN E 51606: Germany; UNI 10635: Italy; SS 1554 36: Sweden; ASTM D 6751: USA; MBTI: Milligan Biotech Inc (Canada); EN 14214: European.

\section{BIODIESEL PRODUCTION}

Biodiesel is produced from vegetable oils, recycled cooking greases and animal fat. A basic overview for manufacturing Biodiesel is provided in Fig. 2 (Chaturvedi et al. 2004).

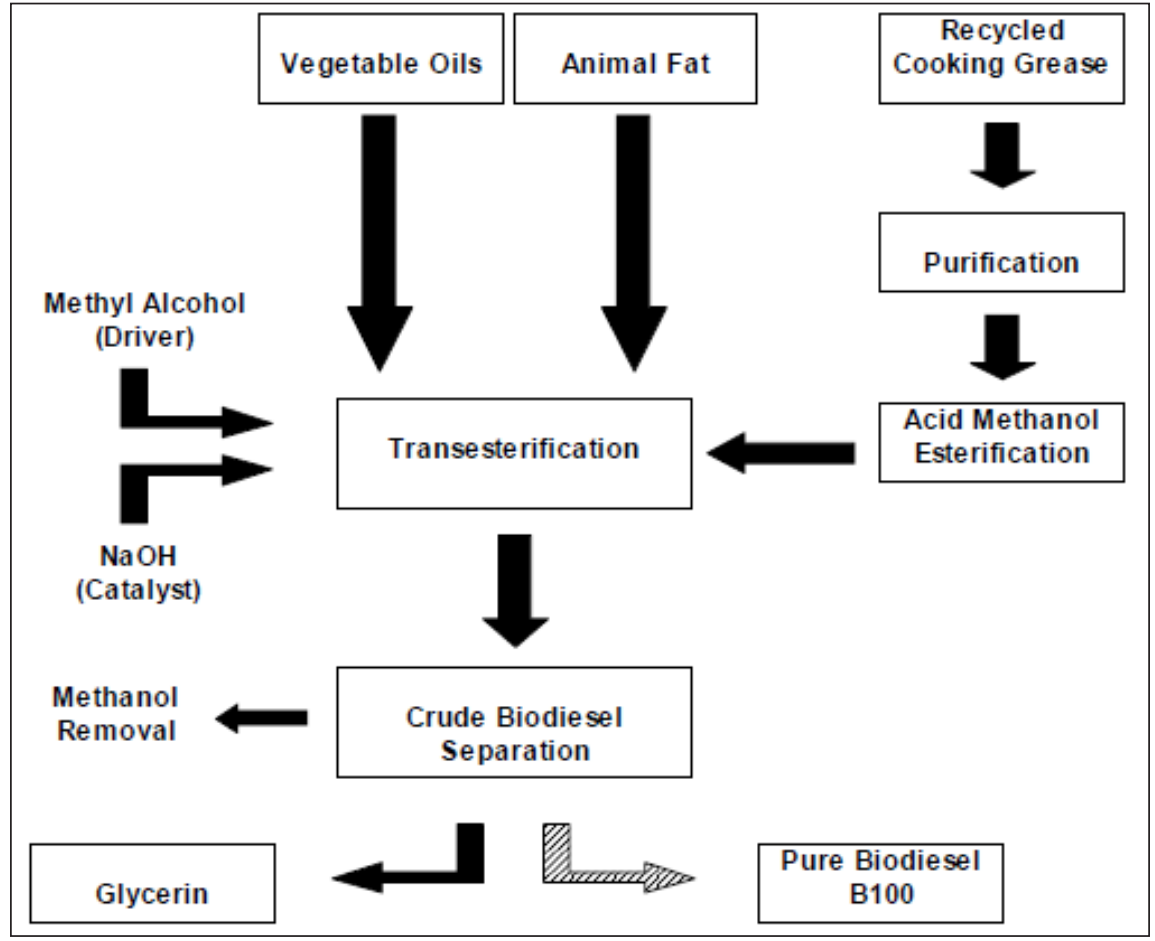

Fig. 2: Basic overview of manufacturing biodiesel

Alternative fuels for Diesel engines have become increasingly important due to increased environmental concerns, and several socioeconomic aspects. In this sense, vegetable oils and animal fats represent a promising alternative to conventional Diesel fuel. However, several chemical properties of oils and fats, among them are the high viscosity and high molecular weight, cause poor fuel atomization and low volatility, leading to incomplete combustion and severe engine deposits, injector coking and piston ring sticking (Bagby, 1987). Research has shown that one way to improve the fuel properties of oils and fats is their transesterification (Petersen et al. 1992; Isigigür et al. 1994; Muniyappa et al. 1996; Zhen et al. 1996; Dorado et al. 2002). Transesterification is a chemical reaction which refers to the conversion of an organic acid ester into another ester of the same acid, so-called biodiesel, using an alcohol, in the presence of a catalyst. This process provides a fuel that can be utilized in unmodified Diesel engines. 
Moreover, several approaches have found that this new fuel seems to emit far less of the most regulated pollutants than standard Diesel fuel, among them is $\mathrm{CO}_{2}$. That means biodiesel contributes to reduce greenhouse gas emissions compared to conventional Diesel (Ali et al. 1994; Chang et al. 1996; Peterson et al. 1996; Scharmer, 1998; McDonnell et al. 1999). Also, the use of biodiesel results in substantially lower emissions of carcinogenic compounds, as compared to conventional Diesel fuel.

Although several approaches have described the use of biodiesel from vegetable oils or animal fats (Peterson et al. 1992; Isigigür et al. 1994; Muniyappa et al. 1996; . Zhen et al. 1996; Ali et al. 1994; Chang et al. 1996; Peterson et al. 1996), research concerning biodiesel from used frying oil, and from waste olive oil in particular, is insufficient, and nonexistent, respectively, and more research is needed. In this sense, the aim of this work is to carry out a preliminary emission test of a Diesel direct injection engine fueled with biodiesel from vegetable seed.

\section{TRACTOR AND THE BIODIESEL}

Tractors and farming have been at the centre for the use of Biodiesel. From an historical perspective, farm vehicles have been more tolerant to fuel types. Bioener $\mathrm{G}$ only recommends the use of the highest quality Biodiesel meeting the European quality standards EN14214. John Deere first showed a biodiesel-fuelled 7600 tractor working on the demo plots at the 1994 Tillage events and revealed that there was no loss of power through the use of Rape Methyl Ester (RME). All tractors produced since 1989 and before the 2002 introduction of common-rail injection systems are capable of running on pure biodiesel, with some minor modifications. However, later models fitted with common-rail engines are only approved to burn a $5 \%$ blend. New Holland approves the use of biodiesel blends of up to $20 \%$ (B20). All New Holland equipment currently in production and powered by $\mathrm{CNH}$ engines, including common-rail, can run on B20 without modifications, alterations to service schedules, restrictions on operating temperatures or additional warranty. Blends greater than $20 \%$ will soon be approved subject to the purchase of an extended warranty. Case and New Holland tractors use identical power plants, Case only approves the use of a 5\% biodiesel blend for common-rail engines. Field testing of $100 \%$ biodiesel is under way. Massey Fergusson, Sisu Diesel engines that were fitted to most MF tractors can run on $100 \%$ biodiesel provided the service interval is reduced by $50 \%$. Tier III Sisu Diesel engines which use common rail injection systems can run on a $20 \%$ blend of biodiesel. These engines are fitted to new MF 6400 (6485 upwards), MF 7400 (MF 7485 upwards) and MF 8400- series. All Perkins engines used in Massey Ferguson machines can run on a blend of $5 \%$ biodiesel. Fendt tractors produced since 1995 can run on $100 \%$ biodiesel. These can also handle $100 \%$ biodiesel because they use twin oil-lubricated fuel injection pumps, thus overcoming the problems of fuel lubrication and rubber seal degradation. Because of biodiesel's strong solvent properties it can cause engine oil dilution. This means oil change intervals must be halved. After the first couple of hours with biodiesel, Fendt recommends changing the fuel filters.

Valtra tractors equipped with common-rail engines runs on up to $20 \%$ bio-diesel. All other engines can be run on up to $100 \%$ biodiesel. Engine performance with bio-diesel is the same as with mineral diesel. It is possible that greater concentrations of biodiesel could be used in the future. Valtra's engines do not need to be modified before using biodiesel. However if a blend of more than $5 \%$ is used, the engine oil, oil filter and fuel filter must be changed twice as often as normal. Sisu Diesel recommends that a separate pre-filter be fitted if biodiesel is used regularly. The water filter should be checked frequently, as biodiesel is more liable to absorb condensed water than normal diesel fuel. All tractors marketed under 
the Deutz-Fahr, Same, Lamborghini and Hurlimann brands equipped with Deutz engines are now able to run on fuel blends containing up to $100 \%$ biodiesel. The key to this is the engines' fuel injection systems, which use injectors fed from individual pumps.

All McCormick and Landini engine suppliers - Perkins, EEA and Cummins - allow the use of a biodiesel blend of no more than 5\% and 95\% EN 950 mineral diesel fuel. Regular oil sampling is recommended. Failures that can be attributed to operating with biodiesel will not be covered by the manufacturer's warranty. Perkins engines can run on a $5 \%$ biodiesel mix without loss of performance or warranty invalidation. Service intervals will remain at 500 hours or as otherwise previously specified. Trials of fuel with a higher proportion of biodiesel are ongoing and Perkins expects to make a statement in the coming year. Cummins power-plants (as used in McCormick and JCB tractors) are capable of handling up to $5 \%$ biodiesel. JCB only allow a $5 \%$ blend of Biodiesel in their vehicles.

In India, Mahindra \& Mahindra launched the first Biodiesel compatible tractor for the Indian market, the Arjun International 75757. The trucks will run on B5 and the company is seeking to introduce B10 complaint vehicles in the future. The new tractors will be able to use five per cent Biodiesel. Company's research and development team has developed a fuel injection system that will allow mixing of five per cent Biodiesel, which will soon become a norm in the country. The tractors will also be able to run without biofuel.

\section{METHODOLOGY}

In the present research the aim was to carry out a preliminary emission test of a diesel (direct injection) engine fueled with biodiesel from jatropha and soya bean in several steady-state operating conditions. The fuel tests were performed with a $610 \mathrm{cc}$, single cylinder, four-stroke, water-cooled, 18.0:1 compression ratio, direct injection diesel engine. The maximum torque was $32.8 \mathrm{Nm}$ at $3000 \mathrm{rpm}$, and the maximum engine power was $11.2 \mathrm{hp}$ at $2250 \mathrm{rpm}$ (DIN 6270-A). The engine was a new to original specifications. Fuel consumptions were measured in different ratios with variations of percentage of diesel and biodiesel. The result has shown in the Table 3.

Experiments were conducted in the following way:

1. First test was with $100 \%$ diesel for about $20 \mathrm{hrs}$.

2. Second test was with 20\% Biodiesel: 80\% Diesel for about $20 \mathrm{hrs}$.

3. Third test was with 50\% Biodiesel: 50\% Diesel for about $20 \mathrm{hrs}$.

4. Fourth test was with $80 \%$ Biodiesel: 20\% Diesel for about 20 hrs

5. Fifth test was with $100 \%$ Biodiesel for about $20 \mathrm{hrs}$.

6. Necessary instrumentation was provided for measuring fuel consumption in each test.

Table 3: Data of fuel consumption

\begin{tabular}{cccccc}
\hline \multirow{2}{*}{ SI No. } & \multicolumn{2}{c}{ Fuel Used } & Duration of test & Fuel consumed & Fuel consumption \\
\cline { 2 - 6 } & Diesel \% & Bio Diesel \% & (hr) & (l) & (l/hr) \\
\hline 1 & 100 & 0 & 2 & 2.3 & 1.15 \\
2 & 100 & 0 & 1.5 & 2.25 & 1.125 \\
3 & 100 & 0 & 1.5 & 1.681 & 1.121
\end{tabular}




\begin{tabular}{|c|c|c|c|c|c|}
\hline 4 & 100 & 0 & 2.5 & 2.9 & 1.16 \\
\hline 5 & 100 & 0 & 2 & 2.4 & 1.2 \\
\hline 6 & 100 & 0 & 1.75 & 2.065 & 1.18 \\
\hline 7 & 100 & 0 & 2.15 & 2.43 & 1.13 \\
\hline 8 & 100 & 0 & 2.25 & 2.59 & 1.15 \\
\hline 9 & 100 & 0 & 2 & 2.32 & 1.16 \\
\hline 10 & 100 & 0 & 2.3 & 2.7 & 1.17 \\
\hline 11 & 80 & 20 & 2 & 2.2 & 1.1 \\
\hline 12 & 80 & 20 & 1.5 & 1.425 & 0.95 \\
\hline 13 & 80 & 20 & 1.5 & 1.395 & 0.93 \\
\hline 14 & 80 & 20 & 2.5 & 2.3 & 0.92 \\
\hline 15 & 80 & 20 & 2 & 1.89 & 0.945 \\
\hline 16 & 80 & 20 & 1.75 & 1.66425 & 0.951 \\
\hline 17 & 80 & 20 & 2.15 & 2.03175 & 0.945 \\
\hline 18 & 80 & 20 & 2.25 & 2.14875 & 0.955 \\
\hline 19 & 80 & 20 & 2 & 1.894 & 0.947 \\
\hline 20 & 80 & 20 & 2.3 & 2.1574 & 0.938 \\
\hline 21 & 50 & 50 & 2 & 1.64 & 0.82 \\
\hline 22 & 50 & 50 & 1.5 & 1.2 & 0.8 \\
\hline 23 & 50 & 50 & 1.5 & 1.215 & 0.81 \\
\hline 24 & 50 & 50 & 2.5 & 2.0625 & 0.825 \\
\hline 25 & 50 & 50 & 2 & 1.66 & 0.83 \\
\hline 26 & 50 & 50 & 1.75 & 1.47 & 0.84 \\
\hline 27 & 50 & 50 & 2.15 & 1.8361 & 0.854 \\
\hline 28 & 50 & 50 & 2.25 & 1.845 & 0.82 \\
\hline 29 & 50 & 50 & 2 & 1.63 & 0.815 \\
\hline 30 & 50 & 50 & 2.3 & 1.955 & 0.85 \\
\hline 31 & 20 & 80 & 2 & 1.456 & 0.728 \\
\hline 32 & 20 & 80 & 1.5 & 1.095 & 0.73 \\
\hline 33 & 20 & 80 & 1.5 & 1.11 & 0.74 \\
\hline 34 & 20 & 80 & 2.5 & 1.8025 & 0.721 \\
\hline 35 & 20 & 80 & 2 & 1.44 & 0.72 \\
\hline 36 & 20 & 80 & 1.75 & 1.2775 & 0.73 \\
\hline 37 & 20 & 80 & 2.15 & 1.58025 & 0.735 \\
\hline 38 & 20 & 80 & 2.25 & 1.65825 & 0.737 \\
\hline 39 & 20 & 80 & 2 & 1.43 & 0.715 \\
\hline
\end{tabular}




\begin{tabular}{lccccc}
40 & 20 & 80 & 2.3 & 1.6629 & 0.723 \\
41 & 0 & 100 & 2 & 1.24 & 0.62 \\
42 & 0 & 100 & 1.5 & 0.915 & 0.61 \\
43 & 0 & 100 & 1.5 & 0.9375 & 0.625 \\
44 & 0 & 100 & 2.5 & 1.545 & 0.618 \\
45 & 0 & 100 & 2 & 1.248 & 0.624 \\
46 & 0 & 100 & 1.75 & 1.106 & 0.632 \\
47 & 0 & 100 & 2.15 & 1.36525 & 0.635 \\
48 & 0 & 100 & 2.25 & 1.3815 & 0.614 \\
49 & 0 & 100 & 2 & 1.25 & 0.625 \\
50 & 0 & 100 & 2.3 & 1.4168 & 0.616 \\
\hline
\end{tabular}

\section{RESULTS AND DISCUSSION}

The results obtained from the experiments were analyzed and results were presented in this section. The average values of fuel consumptions achieved are 1.1546, 0.9581, 0.8264, 0.7279 and 0.6219 respectively with ratio of diesel and biodiesel as follows: 100:0, 80:20, 50:50, 20:80 and 0:100 as given in Table 4 . These values are presented in Table 4. Fig. 3 represents the fuel consumption with different ratio of diesel and biodiesel. It appears from the figure that consumption is decreased with increase in biodiesel ratio and value reaches minimum when biodiesel is $100 \%$.

Table 4: Average fuel consumption

\begin{tabular}{cc}
\hline Mixing ratio & Average Fuel consumption(l/hr) \\
\hline $100: 0 \%$ & 1.1546 \\
$80: 20 \%$ & 0.9598 \\
$50: 50 \%$ & 0.8264 \\
$20: 80 \%$ & 0.7279 \\
$0: 100 \%$ & 0.6219 \\
\hline
\end{tabular}

Table 5: Comparison of results for average fuel consumption

\begin{tabular}{ccccc}
\hline \multirow{2}{*}{ Mixing ratio } & \multicolumn{3}{c}{ Average Fuel consumption (l/hr) } \\
\cline { 2 - 5 } & $\begin{array}{c}\text { Small tractor } \\
\text { Krishi Shakti }\end{array}$ & Aybek et al. 2011 & Ramesh et al. 2014 & Tomic et al. 2013 \\
\hline $100: 0 \%$ & 1.1546 & 6.01 & 3.06 & 12.2 \\
$80: 20 \%$ & 0.9598 & 6.15 & 3.15 & 12.35 \\
$50: 50 \%$ & 0.8264 & - & 3.23 & 12.76 \\
$20: 80 \%$ & 0.7279 & - & - & 13.07 \\
$0: 100 \%$ & 0.6219 & - & - & 12.98 \\
\hline
\end{tabular}




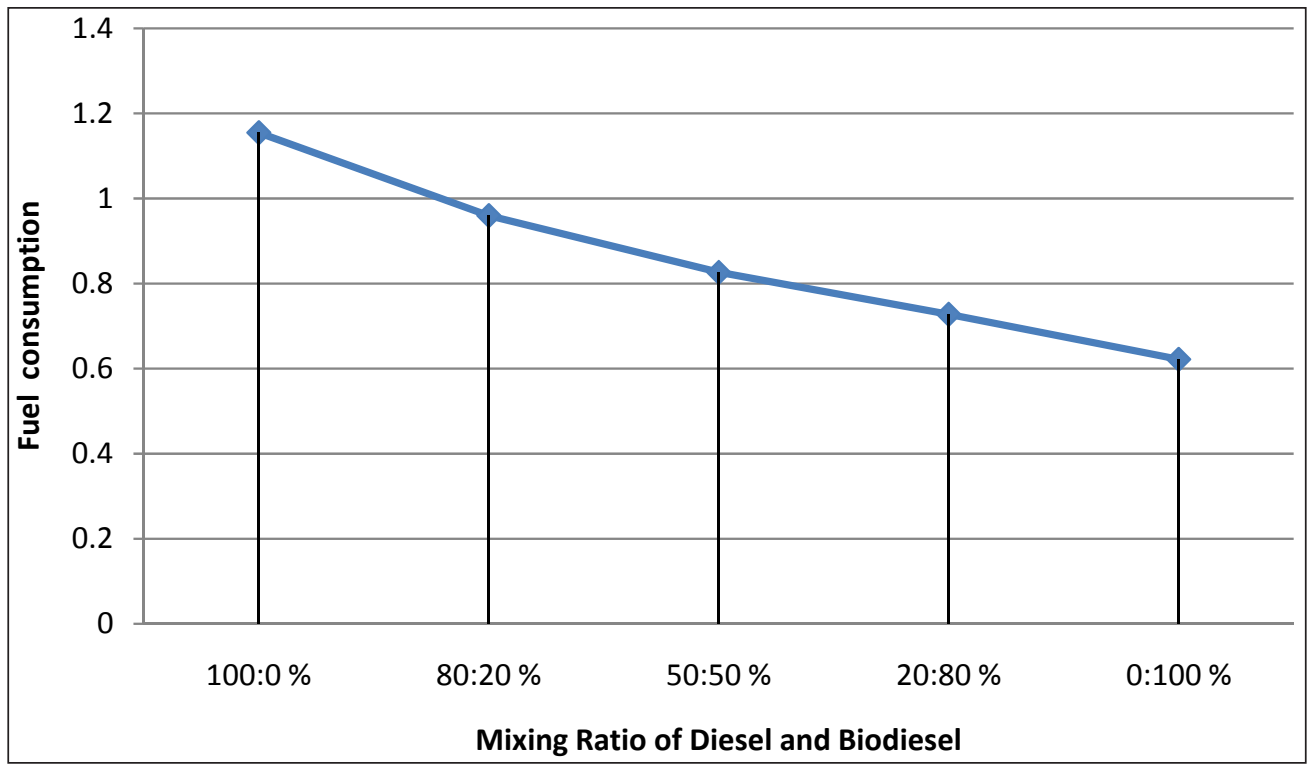

Fig. 3: Effect of diesel and biodiesel combination on fuel consumption

\section{CONCLUSION}

Biodiesel is an environment friendly, safe and low polluting fuel for most diesel engines. It can be mixed with petroleum diesel fuel and stored anywhere. It is made from fresh or waste vegetable oils (triglycerides) which is also a renewable energy source. Biodiesel is the most precious form of renewable energy which can be used directly in an existing or unmodified diesel engine. Biodiesel can be readily adopted as a partial substitute for diesel in today's developing economies of the world. Biodiesel is not only a good choice for environmental reasons but it also keeps the engine in a better health, improving the life of its vital moving components. Thus biodiesel fuel has proved to be a competent, engine friendly and environment friendly substitute for the mineral diesel oil. It may be concluded from the current research that fuel consumption is much less when engine runs with $100 \%$ biodiesel. Thus, saving of fuel leads to saving in farming cost of a farmer.

\section{SUGGESTION}

Bio-fuels will create new markets for agricultural products and encourage rural development because bio-fuels are generated from agricultural crops; they hold enormous potential for farmers. In the near future, it is expected that two-thirds of the people in the developing countries will derive their incomes from agriculture. At the national level, producing more bio-fuels will generate new industries, new technologies, new jobs and new markets. Studies show that bio-diesel reduces carbon-di-oxide emissions to a considerable extent and in some cases all most nearly to zero. Biodiesel helps preserve natural resources, for every unit of energy needed to produce biodiesel, 3.24 units of energy are gained - nearly four times more than diesel. 
Governments should promote bio-fuels within the context of a broader transformation of the transportation sector, since bio-fuels alone will not solve the world's transportation-related energy problems. Biodiesel produced from agricultural crops using current technology cannot sustainably replace fossil-based fuels in terms of its cost and environment impact. However, biodiesel from algae seems to have the potential as the alternative renewable bio-fuel, replacing fossil-based fuels. Algae grow naturally all over the world, either in freshwater or marine water, avoiding the use of agricultural land. Under optimal conditions, it can be grown in massive amounts, almost limitless. Producing renewable bio-fuels from algae will have no conflict with food supply and also contribute to reducing greenhouse gas emissions.

\section{REFERENCES}

1. Agarwal, A.K., Bijwe J. and Das, L.M. 2003. Wear Assessment in a Biodiesel Fueled Compression Ignition Engine. Transactions of the ASME, 125: 820-826.

2. Agarwal, A.K. and Avinash Kumar. 1999. Performance Evaluation and Tribological Studies on a Biodiesel-Fuelled Compression Ignition Engine. Ph.D. thesis, Center for Energy Studies, Indian Institute of Technology, Delhi, India.

3. Ali, Y. and Hanna, M.A. 1994. Alternative diesel fuels from vegetable oils. Bio-resource Technology, 50(2): 153-163.

4. ASTM D 6584 - 00. Test method for determination of Free and Total glycerin in B-100 Biodiesel methyl ester by gas chromatography, ASTM. USA.

5. Aybek, A., Baser, E., Arslan, S. and Ucgul, M. 2011. Determination of the effect of biodiesel use on power take-off performance characteristics of an agricultural tractor in a test laboratory. Trunk L. Agric. For, 35: 103-113.

6. Bagby, M.O. 1987. Vegetable oils for diesel fuel: opportunities for development. ASAE paper no. 871588. American Society of Agricultural Engineers, St. Joseph, MI.

7. Chang, D.Y.Z., Van, G.J.H., Lee, I., Johnson, L.A., Hammond, E.G. and Marley, S.J. 1996. Fuel properties and emissions of soybean oil esters as diesel fuel. J. Am. Oil Chem. Soc., 73: 1549-1555.

8. Chaturvedi, O.P. and Bhattacharya, T.K. 2004. Biodiesel - an alternate fuel. Technical document. Department of FMPE, GBPUA\&T Pantnagar, India.

9. Dorado, M.P., Ballesteros, E., Almeida, J. A de., Schellert, C., Löhrlein, H.P. and Krause, R. 2002. An alkali-catalyzed transesterification process for high free fatty acid waste oils. Trans of the ASAE, 45(3): 525-529.

10. Huang, J., Yang, J., Msangi, S., Rozelle, S. and Weersink, A. 2012. Bio-fuels and the poor: Global impact pathways of bio-fuels on agricultural markets. Food Policy, 37(4): 439-451.

11. Isigigür, A., Karaosmanoglu, F. and Aksoy, H.A. 1994. Methyl ester from safflower seed oil of Turkish origin as a biofuel for diesel engines. Appl Biochem Biotechnol., 45: 103-112.

12. International standards for biodiesel. http://www.svlele.com/biodiesel_std.htm, Accessed on Feb 3, 2016. 
13. IS: 548 (Part I)-1964. Methods of sampling and test for oils and fats. Part 1 - sampling, physical and chemical tests. Bureau of Indian Standards, New Delhi.

14. IS: 15607-2005. Bio-diesel (B100) blend stock for diesel fuel - Specification. Bureau of Indian Standards, New Delhi.

15. Krawczyk Tom. 1996. Biodiesel: Alternative Fuel Makes Inroads but Hurdles Remain. Inform, No. 8: 801-814.

16. Ma, F. and Hanna, M.A. 1999. Biodiesel production: a review. Bio-resource Technology, 70: 1-15.

17. Martin, M. 1996. Diesel fuel derived from vegetable oils VI: Specification and Quality control of Biodiesel. Bioresource Technology, 56: 7-11.

18. McDonnell, K., Ward, S., Leahy, J.J. and McNulty, P. 1999. Properties of rapeseed oil for use as a Diesel fuel extender. J. Am. Oil Chem. Soc., 76: 539-543.

19. Muniyappa, P.R., Brammer, S.C. and Noureddini, H. 1996. Improved conversion of plant oils and animal fats into biodiesel and co-product. Bio-resource Technology, 56: 19-24.

20. Nagaraj, A.M. and PrabhuKumar, G.P. 2003. Effect of injection pressure on engine performance with rice bran oil as biodiesel. In proceedings XVIII National Conference on IC Engine and Combustion, Tiruvanthapur, India, pp. 581-587.

21. Peterson, C.L., Reece, D.L., Cruz, R. and Thompson, J. 1992. A comparison of ethyl and methyl esters of vegetable oil as diesel fuel substitute. Liquid-fuels from renewable resources. In Proceedings of Alternative Energy Conference. American Society of Agricultural Engineers, pp. 99-110.

22. Peterson C, Reece D. 1996. Emissions characteristics of ethyl and methyl ester of rapeseed oil compared with low sulfur diesel control fuel in a chassis dynamometer test of a pickup truck. Trans of the ASAE 39(3): 805-816.

23. Ramesh, B., Palled, V., Veeranouda, M., Sushilendra, N.U. and Anantachar, M. 2014. Dynamic performance of Agricultural Tractor fuelled with Karanja Biodiesel blends for tillage operation. International Journal of Engineering Sciences \& Research Technology, 3(3): 1565-1574.

24. Ryan III, T.W., Dodge, L.G. and Callahan, T.J. 1984. The effects of vegetable oil properties on injection and combustion in two different diesel engines. Journal of the American Oil Chemists Society, 61(10): $1610-1619$.

25. Scharmer, K. 1998. Sustainable agriculture for food, energy and industry, James \& James, London, 844-848.

26. Standards and Warranties, National Biodiesel Board. Web Page, http://www.biodiesel.org/resources/ fuelfactsheets/standards_and_warranties.shtm. Accessed on March 5, 2016.

27. Strong, C., Erickson, C. and Shukla, D. 2004. Evaluation of Biodiesel Fuel: Literature Review. Western Transportation Institute, College of Engineering, Montana State University - Bozeman.

28. Teri Energy Economy Simulation and Evaluation Model. 1998. Asia Leastcost Greenhouse Gas Abatement Strategy-ALGAS. Tata Energy Research Institute, New Delhi. 
29. Tomi, M.D., Lazar, D.S., Radoslav, D.M., Mirko, D.S and Timofej, F.F. 2013. Effects of fossil diesel and biodiesel blends On the performances and emissions of Agricultural tractor engines. Thermal Science, 17(1): 26-278.

30. Yamane, K., Ueta, A. and Shimamoto, Y. 2001. Influence of physical and chemical properties of biodiesel fuels on injection, combustion and exhaust emission characteristics in a direct injection compression ignition engine. International Journal of Engine Research, 2(4): 249-261.

31. Zhen, D. and Hanna, M.A. 1996. Preparation and properties of methyl esters of beef tallow. Bio-resource Technology, 57: 137-142. 